\title{
Developing in Investment Environment in Jordan from the Perspective of Jordan Investments Commission
}

\author{
Mohammad Anhier Al-Froukh ${ }^{1}$ \\ ${ }^{1}$ Omdurman Islamic University, Islamic World Research and Studies Institute, Sudan \\ Correspondence: Mohammad Anhier Al-Froukh, Omdurman Islamic University, Islamic World Research and \\ Studies Institute, Sudan. E-mail: nhier_1984@yahoo.com
}

Received: July 14, 2019

Accepted: August 10, 2019

Online Published: September 5, 2019

doi:10.5539/ijbm.v14n10p116

URL: https://doi.org/10.5539/ijbm.v14n10p116

\begin{abstract}
Globalization; along with its developed technology and wide opened window has facilitated interaction between countries that surpassed import and export. Attracting foreign investments to a country is an added value which helps in developing the workforce within the country and get use from different experiences that other countries employ. From that point, current study seeks to examine the influence of a group of CSF on the investment environment in Jordan from the perspective of Jordan Investment Commission. In order to achieve the aim of study, (412) questionnaire were distributed on senior managers, managers and tram leaders within JIC. Results of study indicated that foreign direct investment is a real means to achieve a number of objectives, including: decrease unemployment, exploitation of natural resources, contribution to the increase of GDP, the abundance of goods for domestic markets, increased exports, and technology transfer. What is important to us in all this is the transfer of technology from developed countries with direct investments to the host countries of this investment, where the transfer of the most efficient and developed means of production, since the foreign investor is always looking for the greatest return through investments in other countries, Create appropriate conditions for this.
\end{abstract}

Keywords: investment environment, critical success factors of investment, Jordan investments commission

\section{Introduction}

Jordan is one of the small developing countries in Asia which has full awareness of the importance of foreign investment in its market. There is a high level of realization regarding how important foreign investments are and to what extent it may help in developing the Jordanian economy into the level of being able to support the country and its citizens. According to Borgers et al. (2015) foreign investments in a country are among the most important factors that help in developing and sustaining the efforts of comprehensive economic efforts. On the other hand, Yıldırım and Yıldırım (2017) noted that a country's economy wouldn't be marked as a good economy if it wasn't based on a combination between local and foreign investments in a way that supports the country's continuous seeking to reach the best and most supportive economic level. As for Jordan, there is a need to increase the attraction of foreign investments due to the limited Jordanian resources, and the need to employ international experiences which may have the ability to increase the level of knowledge and awareness within the Jordanian markets (Kengatharan \& Kengatharan, 2014).

\subsection{Problem Statement}

Jordan has proved its economic openness on the international markets through the multiple trials to attract foreign investment on its land (Salahuddin and Islam, 2008). With the ongoing adoption of technology and internet, Jordan's need of foreign investments increased in order to be able to keep up with the universal changes in terms of politics and economy. In general, Jordan is one of the countries that depends a lot on foreign investments in order to provide job vacancies to its citizens and that is why there has been an endless efforts to prepare the Jordanian environment to embrace more foreign investments and developing projects (Al-Badarneh, 2016).

Jordan has been exposed to a lot of obstacles that hindered the development of investment sector. Zuraiqat and Gharaibeh (2011) noted that the Arabic Spring and the high dependency on Jordan to embrace refugees from different Arabic countries like Libya, Syria, Iraq and Yemen has increased the pressure on the Jordanian government to work on sustaining the highest level of safety and security for those people including economy 
and education. Al-Dmour and Alawi (2008) on the other hand noted that the current political situation with middle east has increased the pressure to Jordan to accept new number on refugees within its economy which increased the need for vacancies and better services in order to be able to serve them and avoid failing in managing the situation.

\subsection{Importance of the Problem}

Al-Dmour and Alawi (2008) that the high inflation rate has increased the Jordanian need for more foreign investment in order to be able to cope with the new circumstances while Al-Nsour (2008) saw that there is an increase within the public budget deficit and public debt which increased the Jordanian need for foreign investment on all levels. Al-Nsour (2008) stated that poverty and unemployment also affected the Jordanian economy and increased its need for foreign investments in order to provide vacancies and jobs for individuals who are literate but unemployed.

Based on the aforementioned argument, and launching from the fact that the Jordanian situation from both political and economic stands increased its need for more foreign investments; there appeared a need to work on increasing foreign investment in Jordan through building better environment that is able to attract investors to the Jordanian space. This current study seeks to examine the factors that influence the degree of attraction of foreign investment in the Jordanian environment. The study took into perspective the variables of (Marketing and Promotions, Economic Openness, Investment behavior, Human Factors, Laws and Legislations and Technological Infrastructure).

From that point, current study seeks to:

- Examine the health of the Jordanian investment environment

- Highlight the factors that most influence the Jordanian investment environment

- Examine the degree of individuals' awareness of the Jordanian investment environment development.

\subsection{Questions and Hypotheses}

Current study seeks to answer the following question:

What are the main factors that have the ability to increase the ability of the Jordanian environment to attract more foreign investments?

From the above aim, objectives and question, the study was built on the following set of hipotheses:

H1: Marketing and Promotions have a significant influence on developing investment environment in Jordan

H2: Economic Openness has a significant influence on developing investment environment in Jordan

H3: Investment behavior Openness has a significant influence on developing investment environment in Jordan

H4: Human Factorshas a significant influence on developing investment environment in Jordan

H5: Laws and Legislations has a significant influence on developing investment environment in Jordan

H6: Technological Infrastructure has a significant influence on developing investment environment in Jordan The following model gives an in-depth investigation of the main aim of study:

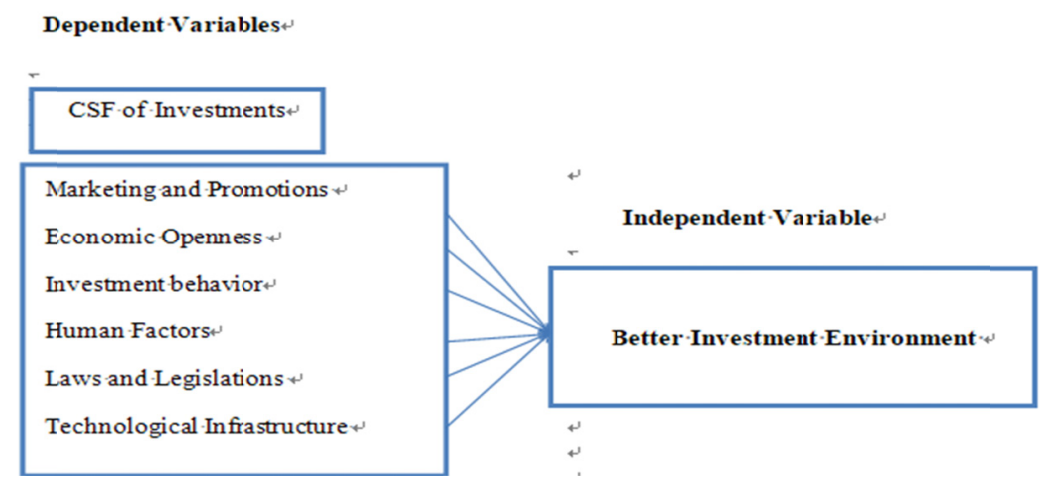

Figure 1. Study model

Source: Al-Badarneh, 2016; Zuraiqat and Gharaibeh, 2011; Al-Dmour and Alawi, 2008; Goryunov, 2004. 


\section{Relevant Literature}

\subsection{Investment Environment}

Investment plays a key role as an economic variable based on its impact on economic system in the world. It is also connected to the levels of income, savings, expenditure, level of employment and economic development. It has played a role in the process of creating mega projects in each country which leads to stability of public savings and capital (Reilly and Brown, 2002).

According to Dauderstädt (2012) investment is effective and important for any country and it is an important element because of the benefits that it brings to society like stability of income, employment and savings. The importance of investment is determined as follows: Improving income of citizens and providing the necessary services, reducing unemployment, increasing capital rates of the country, providing the necessary labor, and creating/ exporting goods and items that are able to meet the needs of citizens (Feldman et al., 2016).

Biau and Pfister (2014) noted that Foreign Direct Investment (FDI) and according to the Organization for Economic Co-operation and Development (OECD) defined international investment as foreign direct investors investing in institutions of another economy. Liu et al. (2013) noted that since 2008 foreign investments became an appropriate alternative to loans for developing countries and especially that 2008 was known for the financial crisis that most developing countries have struggled through.

The attraction of foreign investments is one of the aims pursued by countries as a major motivator in achieving economic development. Governments have adopted plans to attract foreign investment. Many nations are racing to present privileges that encourage foreign investments and pave the way for more foreign investments to enter the country and develop its economy (Moore and Schmitz, 2008).

Kolodkin et al. (2006) argued that attracting foreign investment has gained a lot of attention with globalization theory, economic openness, market economy, and the ITC revolution, and capital flows. This has increased economic integration among countries as according to Duce and Espana (2003), who argued that attracting foreign investment requires an appropriate investment climate like facilitating procedures in a single investment window, avoid bureaucracy, activate modern investment legislation, and granting investors customs and tax privileges.

\subsubsection{Characteristics of the Investment Environment}

In economic theory, investment is one of the components of economic growth represented by GDP growth. Investment is majorly the increase in capital, and the ability to present change in the inventory. investment an appear in different modes, it can appear as fixed assets like machinery and equipment, land, real estate , commodities, raw materials, while the other type of investment can appear in a financial state like shares, bonds, stocks and derivatives (Büthe \& Milner, 2008).

Loewendahl (2018) argued that investment climate plays a role in building and attracting the right type of investments based on the country's needs, aspirations, and demands. From that point, the importance and role of international and regional indicators in detecting the appropriateness and attractiveness of the investment climate have increased as many signs have shown that there is a strong statistical significance between the ranking of the country in these indicators and the amount of foreign direct investment (Mainelli, 2007).

Potter (2002) came arguing that many indicators have the ability to decide and frame the type of foreign investments that can be attracted to a county. Potter (2002) summarized the most prominent indicators as in the following:

\section{- Index of Economic Freedom}

It is used to measure the degree of restrictions adopted by the government regarding economic freedom within the society (Mytelka \& Barclay, 2004). The Index of Economic Freedom is based on 10 factors which includes, trade policy, tax policies, government spending, monetary freedom, freedom of investment, freedom of business, labor market status, individual property rights, freedom of corruption, financial freedom. It is worth to mention here that index of economic freedom can give a general picture about investment climate in the country as it takes into account the developments related to managerial and bureaucratic obstacles and the existence of obstacles to trade, in addition to the rule of law and labor laws.

\section{- $\quad$ KOF Index Globalization}

KOF is considered as one of the most important indicators of integration of countries in the globalization trend, this measures the level of global countries or the global communication of the state and the extent of integration with the outside world (Chung \& Alcácer, 2004). The index of globalization is measured through levels of 
economic globalization, social globalization, and political globalization. Through (2007-2013), KOF Index Globalization has been clearly reflected in FDI inflows to the UAE, ranked 30th in the world leading to foreign direct investment reached $\$ 14$ billion due to the rise in oil prices and attracting investments to the gas and oil industry and services (Mytelka \& Barclay, 2004).

\section{- $\quad$ Digital Infrastructure Readiness Index}

It highlights the key role that the application and development of technologies play as a catalyst for economic growth and prosperity; it also refers to link between level of digital readiness and level of global competitiveness (Ramasamy et al., 2012). The growth in operations of investment and business calls for the need to provide modern information systems and technology to keep up with the global developments, precisely after the global markets'use of information technology for long periods and becoming familiar with and experienced in these areas (Cantwell et al., 2004).

\section{- Human Development}

This indicator is issued annually by the United Nations Development Program (UNDP) since 1990 which ranks countries in three levels in reference to the human development (high, medium, weak) (Mollaesmaeili et al., 2012). Reiter and Steensma (2010) stated that measuring this inductor is based on many factors including (gender empowerment and women's participation in political and economic life). Beverly (2009) argued that the human development measure within developing countries is more dependent on measuring the degree of poverty, deprivation and famine.

\section{- Global Competitiveness Ranking}

This indicator, referred to as GCR has become one of the most important universal indicators with high credibility of the competitiveness of countries and aims to improve the global economic conditions in order to meet the requirements of globalization. The activities of this institution are funded through fees provided by the world's top 1000 companies in addition to the donations and charities (Kusek \& Silva, 2017). The Global Competitiveness Report is characterized by a continuous change in the approach used to measure competitiveness in countries, countries adopt the World Economic Forum in its measure of competitiveness within twelve pillars of competitiveness which are: - Institutions, Infrastructure, Macroeconomic Environment, Health and Basic Education, Higher Education and Training, Commodity Market Effectiveness, Labor Market Feasibility, Capital Market Development, Technological Readiness, Market size, business development, innovation (Snieska \& Zykiene, 2015).

\section{- Corruption Perception Index}

This index reflects the level of improvement in the practice of governments and multinational corporations in combating corruption through promoting transparency and run the needed laws that can stop and prevent corruption in all its forms. Corruption transparency index also includes activities to prevent through the bribery index which is as the worst manifestations of corruption (Johnson and Lee, 2013).

\section{- $\quad$ The Ease of Doing Business Index}

According to Sherif (2016) Ease of Doing Business Index was developed in 2005 and it contained ten subdivisions that are important to business performance and environment. According to Park (2018) the index measures the impact of government laws and procedures on economic conditions and the degree of easiness that a certain body can perform any type of business in a country. EDI also focuses on SMEs sector, with a view to establishing a basis for measuring and comparing the conditions of the business environment in developed countries and developing countries. The sub-indicators are:

- $\quad$ establishment of the project

- $\quad$ acquisition of electricity

- $\quad$ obtaining credit

- $\quad$ payment of taxes

- $\quad$ entry point of contracts

- $\quad$ the license extraction index

- $\quad$ property registration index

- $\quad$ investor protection index

- cross-borders index 


\section{- $\quad$ Project closure index}

\section{The Reality of Investment Environment in Jordan}

The Investment Promotion Law No (16) and its amendments for the year 2000 is an appropriate legislative framework for attracting foreign investments and motivating local investments. It is one of the steps that have been taken by the Jordanian government in order to facilitate international investment for the welfare of the Jordanian citizens.

Understanding Investment Promotion Law is based on focusing on the main requirements that an international project might need including (customs and tax exemptions, transportation and paved roads, distribution of water, gas and petroleum products by pipelines in addition to a protective and preventive law that guarantee the rights of foreign investors (Geltner and Ling, 2007).

There is no doubt that the political, economic and social conditions in the Arab world as a whole limit the flow of Arab investments among Arab countries (Hussein, 2004). Arab investments in these countries face many challenges, including (political instability, internal conflicts, and absence of clear legislation and laws). Arab investments abroad are estimated to be the amount 800 and 1800 billion US dollars (some sources estimated at about 2800 billion US dollars), accumulates in the financial, industrial and service institutions in the United States, Europe and some Asian countries in search of security and stability rather than profits and income.

This undoubtedly creates jobs in these countries at the expense of creating real and effective development in the Arab world and combating poverty and unemployment facing young people Arab society as a whole, especially university graduates and those with high academic qualifications, Masters and PhDs, which generates suffering, frustration and societal tension among these communities, and is reflected in stability and security in many countries through demonstrations, protests, strikes and other security dangerous deeds (Managi, 2012).

According to Al-Shoura and Al-Bakri (2013) Jordan has an interest in investing and developing specific and clear plans and strategies to activate all state bodies to contribute to and remove obstacles that stand in the way of investment. These are many: There is no vision or strategy for investment, confusion in economic policies, regional crises, high prices of energy, bureaucracy, Long delays, multiple approvals, multiple approvals, multiple references, residence instructions, non-promotion of investment, lack of partnership between the private and public sectors, inconsistency of laws, legislation and regulations, preference of personal interest over reformer Motherland, Internal conflicts within state institutions, extortion of investors, excessive taxes and fees, lack of facilities, patronage, moderation, and foreign investors' perception of uncertainty, uncertainties, unstable business environment, increasing current expenditures at the expense of capital expenditures due to price inflation.

\subsubsection{Foreign Investment in Jordan}

According to Abdul-Khaliq et al., (2013) Jordan has overcome the stage of economic transformation by privatizing many service facilities in order to create competition between these sectors and to establish an infrastructure that has helped economic growth throughout the country. It has become the focus of many investors around the world for political stability and security in a volatile region. To attract foreign investment, and put a lot of legislation and laws that protects these investments (Bakir \& Alfawwaz, 2009).

According to Loewe et al. (2008) foreign investment enjoys the incentives and benefits provided for in the Investment Law, including exemption from payment of customs duties and general sales tax. In some cases, the income tax is reduced as there are no restrictions on the percentage of foreign ownership except in a limited number of economic activities requiring a Jordanian partner to $50.000 \mathrm{JD}$ minimum capital requirements for foreign investment (Shotar \& Abdulrazag, 2003). In addition, the minimum capital requirement for foreign investment is JD 50.000 excluding stocks in public shareholding companies and investment in development zones and free zones can be wholly owned by foreign investors.

On the other hand, Loewe et al. (2007) saw that foreign investors enjoy many privileges and guarantees, including the protection of capital against expropriation and the option of resorting to different alternatives to dispute settlement. Foreign investment enjoys the facilitation of registration and licensing services provided by the investment window as well as support in obtaining visas and residence permits for the investor / family and employees as well as other services.

Jordan has an excellent infrastructure; there are no isolated areas of development and modernization. The electricity network reaches all areas and paved roads. All residential areas and all areas of Jordan are covered by wireless coverage. The government relies heavily on the tourism sector where the various countries of the world attract large numbers of tourist groups, making investment sector safe (Siegel et al, 2011). 
Statistics showed that the the value of shares purchased by non-Jordanian investors during the month of October reached JD 65.7 million, representing $37.3 \%$ of total trading volume, while the value of shares sold by them for the same period amounted to JD 41.9 million. Non-Jordanian during the month of October rose by 23.9 million dinars, compared with a decrease of 4.6 million dinars for the same period in 2015 (JIC, 2019).

Also, the value of shares purchased by non-Jordanian investors since the beginning of the year until the end of October reached JD 453.9 million, representing 25.2 percent of total trading volume. Thus, net non-Jordanian investments increased by KD 143.8 million, compared with a decrease of KD 9 million in 2015. In terms of Arab investors, the total value of their purchases since the beginning of the year until the end of October amounted to about JD 357.3 million, representing $78.7 \%$ of the total value of non-Jordanians. The total value of non-Arab purchases amounted to KD 96.6 million Representing $21.3 \%$ of the total purchases of non-Jordanians (Al-Dmour \& Alawi, 2008).

Louzi and Abadi (2011) mentioned that investment plays a major role in increasing the productive capacity of the Jordanian economy and has a significant role in creating job opportunities by investing in expanding production in existing projects and through the employment opportunities generated by investment in new projects established in various economic sectors. One work is more than 50,000 dinars in medium and large projects, and more than 20,000 dinars for the opportunity to work in small projects (Al-Abdulrazag, 2009).

\subsection{Factors that Influence the Investment Environment}

\subsubsection{Marketing and Promotions}

The development of foreign investment in its various forms represents a common denominator for rich and poor countries. Wealthy countries are interested in maintaining their level of economic development. Poor countries are interested in eradicating poverty and raising economic growth (Tang \& Xiong, 2012).

Anadu et al. (2018) noted that economic data and indicators are one of the most important things to measure the strengths and weaknesses of the national economy in any country around the world, and is one of the most important elements for business owners to make their decisions for investment, along with the importance of these data and indicators in the work of accurate economic analysis only figures confirm the strength of the economy from weakness. Marketing and promoting the good side of investment in a country is considered to be one of the valid approaches to attract more foreign investment to a country (Bandura, 2008).

\subsubsection{Economic Openness}

The successive developments and scientific developments have contributed to the expansion of the base of economic openness. This has resulted in more challenges for developing countries that suffer from imbalances in their economic structures and dependence. This has led them to face several difficulties at the economic and social levels. By seeking to restructure their economies by setting them up to compete with each other to attract foreign investment and take advantage of its advantages (Zeibote et al., 2017).

According to Mas'ud et al. (2017) Jordan was one of the countries that recognized the importance of foreign direct investment as a major tool for economic reform and opening up. In order to achieve the desired objectives of these foreign investments, the Jordanian government has taken many corrective measures and enacted laws and legislations in order to provide the suitable investment climate to attract foreign investments in a severe competition by neighboring countries.

According to Watson and Hay (2003) the increasing the performance of the national economy and attracting more investments to maximize achievements requires the stimulation of economic openness since the dawn of history and the world is in a state of mobility and simulation of the continuous development, especially since the last quarter of the twentieth century is witnessing changes and transformations that extended its effects to the time we live, And interrelated among them have taken an impact on economic policy, the most important of which is globalization, where the new world is changing and the economic openness required to keep abreast of developments and catch up with competitiveness (Waluyo, 2018).

\subsubsection{Investment Behavior}

The economic and financial world is based on rigid numbers, but the economic and financial theories not only focus on numbers, but also consider rational choices by individuals who are accurately calculated and structured information available when making a decision to invest or withdraw from a project or otherwise. Many scientific researchers have shown that there are many factors influencing an individual's decision in the financial world. Many researchers believe that psycho-social studies may explain changes in financial markets rather than specialized economics (Novikova et al., 2016). 
Anadu et al. (2018) argued that in applied studies by the American psychologist Daniel Kahneman, people seem to view the loss of money in a different form than that of losing anything else, even if the value of lost money is worthless. The study paved the way for Kahneman to develop another study on behavioral finance, which states that investors' decisions will vary by their emotional and emotional influences at the moment of decision making.

Financial and economic investment decisions are made by human beings, ie, men and women, money and economy, who try to be objective, rational, rational and based on the best mathematical, statistical, technical and analytical techniques before making any final financial decision. But they differ in their readings of events, to the difference of the rule from which they derive this reading. They are often driven by fear of loss and greed. Some specialists forget important investment rules if they fall under the influence of these factors. This is the behavioral finance that changes the behavior of economists and businessmen and their women to decisions manipulated by emotion and fear and psychological reasons (Panizza, 2017).

\subsubsection{Laws and Legislations}

The issue of investment and development is of great importance as it is a challenge for countries that seek to achieve positive indicators in these areas. At the same time, it creates real opportunities to solve the crises of unemployment and weak economy. However, the legal framework for investment protection and development and strengthening the legal system and judicial procedures Achieving reassurance for all parties (state, companies, investors, workers ...) is the basis of the comprehensive renaissance in the state of law and institutions, and from these points comes the importance of creating flexible and lean laws and legislations in order to help attracting more investments of the country and develop its standpoints towards the adoptions of investment within new areas (Charron, 2016).

Economic liberalization is the best way to attract investments, taking into account that the development of trade and the exploitation of available resources is the most necessary use through the adoption of a strategy to integrate the administrative and investment readings and others in order to respond quickly (Moosa, 2002).

Niu et al (2017) stated that the need to find an investment window to identify the economic opportunities available in Jordan and work to promote them in the light of the expected feasibility of them with emphasis on activating the role of the institution in providing information to the foreign investor in addition to the importance of classification of investment alternatives and economic feasibility to achieve the optimal recruitment of resources and the search for prospects and markets, Competitiveness of local industries and export development, which produces the investment climate to attract foreign capital, especially in light of the weak capital of many companies, which hinders the possibility of expansion and increase export capacity (Ferreira et al., 2017).

\subsubsection{Technological Infrastructure}

Hanisch (2019) argued that today, IT infrastructure needs to keep pace with the growth of any organization. Projects often require innovative ways to meet changing business needs by improving flexibility, ensuring rapid technological innovation and delivering high business value. Jordanian government provide efficient, reliable and scalable solutions to support the technological infrastructure through enhancing business performance of technology providers, keep pace with technology for business standards and optimize costs, which in turn will lead to long-term success.

On the other hand, Hanisch (2018) said that foreign direct investment (FDI) is one of the most important means of transferring the latest technological achievements of host countries, as multinational corporations keep pace with and possess the latest technologies and organizational and managerial skills.

In order for technology to attract foreign investment there is a need to strengthen the technological component and research and development processes, by giving greater importance to scientific research and development institutions, and integrating the private sector in the work of these national institutions to apply their outputs to the establishments operating in this sector (Cheng et al., 2017).

\section{Method}

\subsection{Participants' Characteristics}

Participants within current research study were derived from the main entity in Jordan which is responsible for attraction foreign investments to the country. Respondents had the needed information regarding the study as the researcher has met the manager and explained all the procedures related to the study. Then the management has transferred the steps to employees and made sure that they had full understanding of their role. In addition to that, respondents had the full right to withdraw whenever they felt in need, uncomfortable or not convinced with the 
study procedures. They also weren't asked to present any personal information and all information related to the demographic variables were used in secrecy by the researcher only.

\subsection{Sample Size, Power and Precision}

Study population consisted of all workers within the main body in Jordan that is responsible for foreign investment attraction which is Jordan Investment Commission (JIC). A sample of (500) individuals from JIC was chosen to form the sample of study including senior managers, managers and team leaders. After the application of study tool, there appeared to be (412) questionnaires that were valid for analysis which makes the response rate $82.3 \%$ and it was statistically accepted. Gathered data was screened and processed depending on SPSS ed. $21^{\text {st }}$, descriptive statistics, ANOVA and coefficients were used in order to test the questionnaire and develop its results.

\subsection{Measures and Covariates}

A questionnaire was employed as a tool of study. The questionnaire was built by the researcher; it was divided into two main sections, the first took into perspective the demographic variables of study sample while the other section consisted to statements related to the study's dependent variables including (Marketing and Promotions, Economic Openness, Investment behavior, Human Factors, Laws and Legislations and Technological Infrastructure).

\subsection{Research Design}

Quantitative approach was followed in order to achieve the study aim and objectives and answer its questions. Quantitative approach was seen to be suitable due to its ability to acquire data from a large sample; this data is numerical and might be useful in order to read the nature of respondents' answers to the tool of study.

\section{Results}

Following section presented results of analyzing study's gathered data, the section included results of demographic variables, results of responses to the questionnaire statements, reliability test and hypotheses testing.

\subsection{Statistics and Data Analysis}

\subsubsection{Participants' Flow}

Table 1. Sample characteristics according to gender

\begin{tabular}{llllll}
\hline & & Frequency & Percent & Valid Percent & Cumulative Percent \\
\hline Valid & Male & 331 & 80.3 & 80.3 & 80.3 \\
& Female & 81 & 19.7 & 19.7 & 100.0 \\
& Total & 412 & 100.0 & 100.0 & \\
\hline
\end{tabular}

Results indicated in table (1) that $80.3 \%$ of respondents were males compared to $19.7 \%$ females. This indicated that the majority of managers and team leaders within JIC are males.

Table 2. Sample characteristics according to age

\begin{tabular}{llllll}
\hline & & Frequency & Percent & Valid Percent & Cumulative Percent \\
\hline Valid & $22-27$ & 22 & 5.3 & 5.3 & 5.3 \\
& $28-33$ & 114 & 27.7 & 27.7 & 33.0 \\
& $34-39$ & 151 & 36.7 & 36.7 & 69.7 \\
& +40 & 125 & 30.3 & 30.3 & 100.0 \\
& Total & 412 & 100.0 & 100.0 & \\
\hline
\end{tabular}

Results indicated in table 2 that $80.3 \%$ of respondents were within the age range of $34-39$ years old scoring $36.7 \%$ of the total sample. The lowest age range appeared to be for individuals within the age range 22-27 years old scoring $5.3 \%$ which indicated the high level of experiences in JIC. 
Table 3. Sample characteristics according to education

\begin{tabular}{llllll}
\hline & & Frequency & Percent & Valid Percent & Cumulative Percent \\
\hline valid & BA & 183 & 44.4 & 44.4 & 44.4 \\
& MA & 181 & 43.9 & 43.9 & 88.3 \\
& PhD & 48 & 11.6 & 11.6 & 98.1 \\
& Total & 412 & 100.0 & 100.0 & \\
\hline
\end{tabular}

In table 3 above, it was revealed that the majority of respondents were BA degree forming $44.4 \%$ of the sample, while in the $2^{\text {nd }}$ rank there appeared individuals with MA degree forming $43.9 \%$.

Table 4. Sample characteristics according to experience

\begin{tabular}{llllll}
\hline & & Frequency & Percent & Valid Percent & Cumulative Percent \\
\hline Valid & $2-5$ & 23 & 5.6 & 5.6 & 39.1 \\
& $6-9$ & 138 & 33.5 & 33.5 & 33.5 \\
& $10-13$ & 78 & 18.9 & 18.9 & 58.0 \\
& +14 & 173 & 42.0 & 42.0 & 100.0 \\
& Total & 412 & 100.0 & 100.0 & \\
\hline
\end{tabular}

Results of respondents' regarding the experience variable recorded the highest percentage for +14 years of experience with frequency of 137 respondents. The $2^{\text {nd }}$ rank came for respondents who had experience of 6-9 years scoring $33.5 \%$ with frequency of 138 individuals.

Table 5. Questionnaire analysis

\begin{tabular}{|c|c|c|c|c|c|}
\hline & $\mathrm{N}$ & Minimum & Maximum & Mean & $\begin{array}{l}\text { Std. } \\
\text { Deviation }\end{array}$ \\
\hline \multicolumn{6}{|l|}{ Investment environment in Jordan } \\
\hline $\begin{array}{l}\text { Developing the investment environment can provide jobs and vacancies } \\
\text { to individuals }\end{array}$ & 412 & 1.0 & 5.0 & 3.842 & .9395 \\
\hline Jordanian investment environment is healthy and supportive & 412 & 2.0 & 5.0 & 4.104 & .5889 \\
\hline $\begin{array}{l}\text { There is always a chance to develop the Jordanian investment } \\
\text { environment }\end{array}$ & 412 & 1.0 & 5.0 & 3.731 & .8588 \\
\hline $\begin{array}{l}\text { Without foreign investment poverty and unemployment will increase in } \\
\text { Jordan }\end{array}$ & 412 & 2.0 & 5.0 & 4.012 & 6992 \\
\hline There are many chances in Jordan which an support foreign investments & 412 & 1.0 & 5.0 & 3.998 & .7028 \\
\hline \multicolumn{6}{|l|}{ CSF of investment } \\
\hline \multicolumn{6}{|l|}{ Marketing and promotions } \\
\hline Marketing the nature of Jordan may help attracting more investment & 412 & 1.0 & 5.0 & 3.796 & .8808 \\
\hline Jordanian environment must be based on international marketing & 412 & 1.0 & 5.0 & 3.568 & .8559 \\
\hline Technology is a major part in marketing for more investments & 412 & 1.0 & 5.0 & 3.857 & .8143 \\
\hline $\begin{array}{l}\text { Marketing and promotions can uncover the hidden chances in the } \\
\text { investment environment }\end{array}$ & 412 & 1.0 & 5.0 & 3.847 & .7567 \\
\hline \multicolumn{6}{|l|}{ Economic Openness } \\
\hline Openness on other investment opportunities in other countries is helpful & 412 & 2.0 & 5.0 & 4.012 & .7130 \\
\hline Jordan is widely known for its economic openness & 412 & 1.0 & 5.0 & 3.617 & .7945 \\
\hline Learning from other experiences within countries is beneficial & 412 & 1.0 & 5.0 & 3.604 & .7807 \\
\hline There is always a chance to get experiences from other countries & 412 & 1.0 & 5.0 & 3.638 & .7201 \\
\hline \multicolumn{6}{|l|}{ Investment Behavior } \\
\hline Economic policies in Jordan are supportive to international investments & 412 & 1.0 & 5.0 & 3.626 & .8406 \\
\hline There are many successful examples of foreign investments in Jordan & 412 & 1.0 & 5.0 & 3.684 & .8298 \\
\hline $\begin{array}{l}\text { The Jordanian environment still needs a lot of amendments to attract } \\
\text { investments }\end{array}$ & 412 & 2.0 & 5.0 & 3.646 & .7865 \\
\hline $\begin{array}{l}\text { There is a low level of awareness regarding the benefits of foreign } \\
\text { investments }\end{array}$ & 412 & 1.0 & 5.0 & 3.672 & .7229 \\
\hline
\end{tabular}




\begin{tabular}{|c|c|c|c|c|c|}
\hline $\begin{array}{l}\text { The Jordanian behavior regarding investment is flexible and willing to } \\
\text { accept change }\end{array}$ & 412 & 1.0 & 5.0 & 3.665 & .8191 \\
\hline \multicolumn{6}{|l|}{ Human Factor } \\
\hline There are many talented workforce in Jordan & 412 & 1.0 & 5.0 & 3.563 & .8477 \\
\hline Talented workforce is oppressed due to unemployment & 412 & 1.0 & 5.0 & 3.672 & .8497 \\
\hline The human factor in Jordan is beneficial for foreign investments & 412 & 2.0 & 5.0 & 3.852 & .6834 \\
\hline Workforce in Jordan is strong and well-educated & 412 & 1.0 & 5.0 & 3.621 & .8892 \\
\hline \multicolumn{6}{|l|}{ Laws and Legislations } \\
\hline $\begin{array}{l}\text { Some legislative rules in Jordan aren't helpful to attract foreign } \\
\text { investments }\end{array}$ & 412 & 1.0 & 5.0 & 3.590 & .7887 \\
\hline The investment commission is doing its best to attract more investments & 412 & 1.0 & 5.0 & 3.682 & .8619 \\
\hline Some rules and laws are oppressive which prevents foreign investments & 412 & 1.0 & 5.0 & 3.524 & .9238 \\
\hline $\begin{array}{l}\text { Some amendments on laws and regulations may help attract foreign } \\
\text { investments }\end{array}$ & 412 & 1.0 & 5.0 & 3.697 & .7367 \\
\hline \multicolumn{6}{|l|}{ Technological infrastructure } \\
\hline $\begin{array}{l}\text { Jordan enjoys a good technological infrastructure to support } \\
\text { investments }\end{array}$ & 412 & 1.0 & 5.0 & 3.745 & .7865 \\
\hline The infrastructure in Jordan is supportive and well-built & 412 & 1.0 & 5.0 & 3.964 & .8261 \\
\hline Internet and technology are available in Jordan with the best qualities & 412 & 1.0 & 5.0 & 4.010 & .6506 \\
\hline There is a high level of awareness regarding technology in Jordan & 412 & 1.0 & 5.0 & 4.007 & .6993 \\
\hline $\begin{array}{l}\text { The Jordanian investment commission is well-equipped with } \\
\text { technological infrastructure }\end{array}$ & 412 & 2.0 & 5.0 & 4.044 & .6340 \\
\hline Valid N (listwise) & 412 & & & & \\
\hline
\end{tabular}

Examining the results of the questionnaire analysis, it was seen that there is a positive attitude from participants towards the above questions. This appeared through the mean of the paragraphs which scored higher than 3.00 referring to the paragraph as a good indicator.

\subsection{Reliability Test}

A reliability test was carried out using Cronbachs' alpha, The result showed a value of $(0.956)$ for the all items as well as alpha for each variable is greater than accepted percent 0.60 , which is a reasonable value indicating the tool consistency that enhanced its use for the study

Table 6. Variable analysis

\begin{tabular}{llllll}
\hline & $\mathrm{N}$ & Minimum & Maximum & Mean & Std. Deviation \\
\hline Marketing and promotions & 412 & 1.00 & 5.00 & 3.7670 & .70432 \\
Economic openness & 412 & 1.75 & 5.00 & 3.7178 & .61561 \\
Investment behavior & 412 & 2.00 & 5.00 & 3.6587 & .67859 \\
Humanfactor & 412 & 1.75 & 5.00 & 3.6772 & .56363 \\
Laws and legislations & 412 & 1.25 & 5.00 & 3.6232 & .69375 \\
Technological infrastructure & 412 & 1.60 & 5.00 & 3.9539 & .57685 \\
Dep & 412 & 2.00 & 5.00 & 3.9374 & .59883 \\
Valid N (listwise) & 412 & & & & \\
\hline
\end{tabular}

Examining the results of the questionnaire analysis, it was seen that there is a positive attitude from participants towards the above variables. This appeared through the mean of the paragraphs which scored higher than 3.00 referring to the paragraph as a good indicator.

\subsection{Hypotheses Testing}

\section{Main Hypothesis: CSF of investment has an impact on the investment environment in Jordan}

This hypothesis was tested using multiple regression analysis. With the $r$ value of 0.82 , it was confirmed that independent variables and dependent variable are strongly correlated. Again, with 138.223 as the value of $F$ at 0.05 significant at (0.05), it is confirmed that there is an impact of the independent variables on the dependent variable. 
Table 7. Model Summary

\begin{tabular}{lllll}
\hline Model & R & R Square & Adjusted R Square & Std. Error of the Estimate \\
\hline 1 & $.820^{\mathrm{a}}$ & .672 & .667 & .34555 \\
\hline
\end{tabular}

Table 8. ANOVA

\begin{tabular}{llllll}
\hline Model & & Sum of Squares & df & Mean Square & F \\
\hline 1 & Regression & 99.026 & 6 & 16.504 & 138.223 \\
& Residual & 48.358 & 405 & .119 & $.000^{\mathrm{b}}$ \\
& Total & 147.384 & 411 & & \\
\hline
\end{tabular}

Table 9. Coefficient

\begin{tabular}{|c|c|c|c|c|c|c|}
\hline \multicolumn{2}{|c|}{ Model } & \multicolumn{2}{|c|}{ Unstandardized Coefficients } & \multirow{2}{*}{$\begin{array}{l}\text { Standardized Coefficients } \\
\text { Beta }\end{array}$} & \multirow[t]{2}{*}{$\mathrm{t}$} & \multirow[t]{2}{*}{ Sig. } \\
\hline & & $\mathrm{B}$ & Std. Error & & & \\
\hline \multirow[t]{7}{*}{1} & (Constant) & .908 & .131 & & 6.922 & .000 \\
\hline & Marketing & .573 & .034 & .674 & 17.099 & .000 \\
\hline & Economic & -.033 & .057 & -.034 & -.576 & .565 \\
\hline & Investment & .087 & .052 & .099 & 1.676 & .095 \\
\hline & Human & .113 & .059 & .106 & 1.908 & .057 \\
\hline & Laws & -.191 & .042 & -.221 & -4.553 & .000 \\
\hline & Technological & .240 & .048 & .231 & 5.012 & .000 \\
\hline
\end{tabular}

Sub-Hypotheses: H1: Marketing and Promotions have a significant influence on developing investment environment in Jordan

This hypothesis was tested using linear regression analysis. With the $r$ value of 0.789 , it was confirmed that independent variable and dependent variable are strongly correlated. Again, with 25.962 as the value of $t$ at 0.05 significant at (0.05), it is confirmed that marketing and promotion have a significant influence on developing investment environment in Jordan.

Table 10. Model summary

\begin{tabular}{lllll}
\hline Model & R & R Square & Adjusted R Square & Std. Error of the Estimate \\
\hline 1 & $.789^{\mathrm{a}}$ & .622 & .621 & .36873 \\
\hline
\end{tabular}

Table 11. ANOVA

\begin{tabular}{llllll}
\hline Model & & Sum of Squares & df & Mean Square & F \\
\hline 1 & Regression & 91.640 & 1 & 91.640 & 674.017 \\
& Residual & 55.744 & 410 & .136 & $.000^{\mathrm{b}}$ \\
& Total & 147.384 & 411 & & \\
\hline
\end{tabular}

Table 12. Coefficients

\begin{tabular}{|c|c|c|c|c|c|c|}
\hline \multirow{2}{*}{\multicolumn{2}{|c|}{ Model }} & \multicolumn{2}{|c|}{ Unstandardized Coefficients } & \multirow{2}{*}{$\begin{array}{l}\text { Standardized Coefficients } \\
\text { Beta }\end{array}$} & \multirow[t]{2}{*}{$\mathrm{t}$} & \multirow[t]{2}{*}{ Sig. } \\
\hline & & $\mathrm{B}$ & Std. Error & & & \\
\hline \multirow[t]{2}{*}{1} & (Constant) & 1.412 & .099 & & 14.267 & .000 \\
\hline & Marketing & .670 & .026 & .789 & 25.962 & .000 \\
\hline
\end{tabular}

\section{H2: Economic Openness has a significant influence on developing investment environment in Jordan}

This hypothesis was tested using linear regression analysis. With the $r$ value of 0.55 , it was confirmed that independent variable and dependent variable are moderately correlated. Again, with 13.32 as the value of $t$ at 0.05 significant at (0.05), it is confirmed that Economic Openness has a significant influence on developing investment environment in Jordan 
Table 13. Model summary

\begin{tabular}{lllll}
\hline Model & R & R Square & Adjusted R Square & Std. Error of the Estimate \\
\hline 1 & $.550^{\mathrm{a}}$ & .302 & .300 & .50090 \\
\hline
\end{tabular}

Table 14. ANOVA

\begin{tabular}{llllll}
\hline Model & & Sum of Squares & df & Mean Square & F \\
\hline 1 & Regression & 44.516 & 1 & 44.516 & 177.429 \\
& Residual & 102.868 & 410 & .251 & $.000^{\mathrm{b}}$ \\
& Total & 147.384 & 411 & & \\
\hline
\end{tabular}

Table 15. Coefficients

\begin{tabular}{|c|c|c|c|c|c|c|}
\hline \multirow{2}{*}{\multicolumn{2}{|c|}{ Model }} & \multicolumn{2}{|c|}{ Unstandardized Coefficients } & \multirow{2}{*}{$\begin{array}{l}\text { Standardized Coefficients } \\
\text { Beta }\end{array}$} & \multirow[t]{2}{*}{$\mathrm{t}$} & \multirow[t]{2}{*}{ Sig. } \\
\hline & & $\mathrm{B}$ & Std. Error & & & \\
\hline \multirow[t]{2}{*}{1} & (Constant) & 1.950 & .151 & & 12.892 & .000 \\
\hline & Economic & .535 & .040 & .550 & 13.320 & .000 \\
\hline
\end{tabular}

\section{H3: Investment behavior Openness has a significant influence on developing investment environment in Jordan}

This hypothesis was tested using linear regression analysis. With the $r$ value of 0.63 ,it was confirmed that independent variable and dependent variable are strongly correlated. Again, with 16.42 as the value of $t$ at 0.05 significant at (0.05), it is confirmed that Investment behavior Openness has a significant influence on developing investment environment in Jordan

Table 16. Model Summary

\begin{tabular}{lllll}
\hline Model & R & R Square & Adjusted R Square & Std. Error of the Estimate \\
\hline 1 & $.630^{\mathrm{a}}$ & .397 & .395 & .46569 \\
\hline
\end{tabular}

Table 17. ANOVA

\begin{tabular}{llllll}
\hline Model & & Sum of Squares & df & Mean Square & F \\
\hline 1 & Regression & 58.471 & 1 & 58.471 & 269.621 \\
& Residual & 88.914 & 410 & .217 & $.000^{\mathrm{b}}$ \\
& Total & 147.384 & 411 & & \\
\hline
\end{tabular}

Table 18. Coefficients

\begin{tabular}{|c|c|c|c|c|c|c|}
\hline \multirow{2}{*}{\multicolumn{2}{|c|}{ Model }} & \multicolumn{2}{|c|}{ Unstandardized Coefficients } & \multirow{2}{*}{$\begin{array}{l}\text { Standardized Coefficients } \\
\text { Beta }\end{array}$} & \multirow[t]{2}{*}{$\mathrm{t}$} & \multirow[t]{2}{*}{ Sig. } \\
\hline & & $\mathrm{B}$ & Std. Error & & & \\
\hline \multirow[t]{2}{*}{1} & (Constant) & 1.904 & .126 & & 15.114 & .000 \\
\hline & Investment & .556 & .034 & .630 & 16.420 & .000 \\
\hline
\end{tabular}

\section{H4: Human Factorshas a significant influence on developing investment environment in Jordan}

This hypothesis was tested using linear regression analysis. With the $r$ value of 0.484 , it was confirmed that independent variable and dependent variable are moderately correlated. Again, with 11.184 as the value of $t$ at 0.05 significant at (0.05), it is confirmed that Human Factors has a significant influence on developing investment environment in Jordan

Table 19. Model summary

\begin{tabular}{lllll}
\hline Model & $\mathrm{R}$ & R Square & Adjusted R Square & Std. Error of the Estimate \\
\hline 1 & $.484^{\mathrm{a}}$ & .234 & .232 & .52482 \\
\hline
\end{tabular}


Table 20. NOVA

\begin{tabular}{llllll}
\hline Model & & Sum of Squares & df & Mean Square & F \\
\hline 1 & Regression & 34.454 & 1 & 34.454 & 125.089 \\
& Residual & 112.930 & 410 & .275 & $.000^{\mathrm{b}}$ \\
& Total & 147.384 & 411 & & \\
\hline
\end{tabular}

Table 21. Coeffiient

\begin{tabular}{|c|c|c|c|c|c|c|}
\hline \multirow{2}{*}{\multicolumn{2}{|c|}{ Model }} & \multicolumn{2}{|c|}{ Unstandardized Coefficients } & \multirow{2}{*}{$\begin{array}{l}\text { Standardized Coefficients } \\
\text { Beta }\end{array}$} & \multirow[t]{2}{*}{$\mathrm{t}$} & \multirow[t]{2}{*}{ Sig. } \\
\hline & & $\mathrm{B}$ & Std. Error & & & \\
\hline \multirow[t]{2}{*}{1} & (Constant) & 2.048 & .171 & & 11.989 & .000 \\
\hline & Human & .514 & .046 & .484 & 11.184 & .000 \\
\hline
\end{tabular}

H5: Laws and Legislations has a significant influence on developing investment environment in Jordan

This hypothesis was tested using linear regression analysis. With the $r$ value of 0.311 , it was confirmed that independent variable and dependent variable are moderately correlated. Again, with 6.629 as the value of $t$ at 0.05 significant at (0.05), it is confirmed that Laws and Legislations has a significant influence on developing investment environment in Jordan

Table 22. Model Summary

\begin{tabular}{lllll}
\hline Model & R & R Square & Adjusted R Square & Std. Error of the Estimate \\
\hline 1 & $.311^{\mathrm{a}}$ & .097 & .095 & .56980 \\
\hline
\end{tabular}

Table 23. ANOVA

\begin{tabular}{llllll}
\hline Model & & Sum of Squares & df & Mean Square & F \\
\hline 1 & Regression & 14.269 & 1 & 14.269 & 43.949 \\
& Residual & 133.115 & 410 & .325 & $.000^{\mathrm{b}}$ \\
& Total & 147.384 & 411 & & \\
\hline
\end{tabular}

Table 24. Coefficient

\begin{tabular}{|c|c|c|c|c|c|c|}
\hline \multirow{2}{*}{\multicolumn{2}{|c|}{ Model }} & \multicolumn{2}{|c|}{ Unstandardized Coefficients } & Standardized Coefficients & \multirow[t]{2}{*}{$\mathrm{t}$} & \multirow[t]{2}{*}{ Sig. } \\
\hline & & $\mathrm{B}$ & Std. Error & Beta & & \\
\hline \multirow[t]{2}{*}{1} & (Constant) & 2.964 & .149 & & 19.835 & .000 \\
\hline & Laws & .269 & .041 & .311 & 6.629 & .000 \\
\hline
\end{tabular}

H6: Technological Infrastructure has a significant influence on developing investment environment in Jordan

This hypothesis was tested using linear regression analysis. With the $r$ value of 0.493 , it was confirmed that independent variable and dependent variable are moderately correlated. Again, with 11.469 as the value of $t$ at 0.05 significant at (0.05), it is confirmed that Technological Infrastructure has a significant influence on developing investment environment in Jordan

Table 25. Model Summary

\begin{tabular}{lllll}
\hline Model & $\mathrm{R}$ & $\mathrm{R}$ Square & Adjusted R Square & Std. Error of the Estimate \\
\hline 1 & $.493^{\mathrm{a}}$ & .243 & .241 & .52169 \\
\hline
\end{tabular}


Table 26. ANOVA

\begin{tabular}{lllllll}
\hline Model & & Sum of Squares & df & Mean Square & F & Sig. \\
\hline 1 & Regression & 35.798 & 1 & 35.798 & 131.531 & $.000^{\mathrm{b}}$ \\
& Residual & 111.587 & 410 & .272 & & \\
& Total & 147.384 & 411 & & & \\
\hline
\end{tabular}

Table 27. Coefficient

\begin{tabular}{|c|c|c|c|c|c|c|}
\hline \multirow{2}{*}{\multicolumn{2}{|c|}{ Model }} & \multicolumn{2}{|c|}{ Unstandardized Coefficients } & \multirow{2}{*}{$\begin{array}{l}\text { Standardized Coefficients } \\
\text { Beta }\end{array}$} & \multirow[t]{2}{*}{$\mathrm{t}$} & \multirow[t]{2}{*}{ Sig. } \\
\hline & & $\mathrm{B}$ & Std. Error & & & \\
\hline \multirow[t]{2}{*}{1} & (Constant) & 1.915 & .178 & & 10.741 & .000 \\
\hline & Technological & .512 & .045 & .493 & 11.469 & .000 \\
\hline
\end{tabular}

\section{Discussion}

Current study aimed at examining the influence of a set of variables on the investment environment in Jordan. Through applying a questionnaire on (412) senior manager, manager, and team leader within Jordan investment commission it appeared that the chosen set of variables (Marketing and Promotions, Economic Openness, Investment behavior, Human Factors, Laws and Legislations, Technological Infrastructure). In other words, it appeared that the set of variables above do have an influence in developing the investment environment in Jordan and help in creating a better suited environment that is more able to accept foreign investments.

Through the analysis, it appeared that the most influential variables of all in developing the investment environment in Jordan were marketing and promotions which scored an R value of $\left(.789^{\mathrm{a}}\right)$ and in the $2^{\text {nd }}$ rank came investment behavior which scored the $\mathrm{R}$ value of $\left(.630^{\mathrm{a}}\right)$. Results of study managed to give an indication that investment environment in Jordan should be built on a strong base of marketing which helps in promoting the nature of Jordan and its ability to accept foreign investments in order to support the Jordanian economy and develop its outcomes. On the other hand, the investment behavior of the Jordanian bodies may help in attracting more investors due to the welcoming environment that might be generated along with the ongoing sought to create a window that adopts foreign investors.

Investment is a key factor in the quest to eradicate poverty in the world. Countries that open their doors to world trade usually grow faster, are able to innovate, improve productivity, and provide greater incomes and opportunities for their people. Trade openness also benefits low-income countries by providing affordable goods and services to their consumers. Through trade and global value chains, integration into the global economy helps to promote economic growth and reduce poverty at the local and global levels.

Economic openness came in the $3^{\text {rd }}$ rank of influence scoring an $\mathrm{R}$ value of $\left(.550^{\mathrm{a}}\right)$ and proofing that economic openness of the country on other nations experiences in investment can help in enriching the Jordanian economy into being able to choose what most suited investment sector for the country.

Generally speaking, investment in Jordan faces a lot of obstacles as according to study sample's response to the questionnaire, among these obstacles are the inefficient or inadequate transport systems, logistics or customs, weak networking in the areas of telecommunications, financial markets or information technology, complex regulatory environments discourage new investments, and anti-competitive behavior by major market players or clusters that stifle innovation, productivity, or market growth.

The importance of investment comes from being a tool that increases the production capacity of the host country. In Jordan, many legislations and laws regulating foreign direct investment have been enacted in order to support the national economy, provide foreign currency, provide employment opportunities and achieve comprehensive economic development. Accordingly, a number of laws and regulations have been issued in Jordan to encourage foreign investment since the early 1950s, which were in line with the economic and social development of the country.

The Jordanian laws related to investment include a large number of facilities for investors to provide an adequate investment climate without any obstacles. These facilities include tax and customs exemptions, and also on income, profits, social service taxes, buildings and land, incentives related to the transfer of capital, Foreigners, and capital returns

The future of Jordan, facing economic and social challenges, combating poverty and unemployment, and generating jobs requires reconsidering investment, activating its laws, and choosing national cadres dedicated to 
work and loyalty to serve the country and the citizen.There are some solutions proposed to contribute to attract investment to Jordan can be summarized as follows:

It appeared through the analysis that there is a need to work to identify national priorities and identify the most attractive economic sectors for investment and the establishment of one umbrella for all procedures and regulations and regulations governing investment work in Jordan, similar to what is happening in developed countries.

In addition to that, there must be a state to work to restore confidence in Jordanian businessmen abroad and strive to recover part of their investments to their country and invest in the national economy to advance the desired economic and social development.

The analysis showed an importance state to establish a comprehensive database of Jordanian investors outside the borders of the country to establish long-term partnership with them now and in the future and continuous communication for the purpose of motivating them to invest in their country or at least marketing the investment environment in Jordan through them.

The role of raising the level of agility of government performance in relation to the mechanism and procedures of investment is also crucial, this can happen through decision-making and the establishment of the 'investment mentality' in the government apparatus away from the 'bureaucratic mentality' unjustified and create unreasonable obstacles because those who wish to invest have full intention of cooperation.

Based on the above argument of study conclusion, researcher recommended the following:

- To activate the economic and investment role of the Jordanian embassies in some countries of the world, especially those that are expected to attract foreign investments in specific investment sectors and in accordance with national priorities attracting investment. In this context, we must enrich the investment marketing side of those who are marketing the investment environment in Jordan to foreign countries through our embassies abroad so that investors can be contacted in a 'common language'.

- To consolidate the approach of marketing the investment environment in Jordan to some governmental and independent institutions and allocate the necessary marketing budgets to be the main guide for its objectives and strategies and the mechanism and criteria for evaluating its performance to form a constant incentive to attract investment and develop tools marketed according to international standards.

\section{References}

Abdul-Khaliq, S., Soufan, T., \& Shihab, R. A. (2013). Intensive Economic Growth in Jordan during 1978-2010. International Journal of Business and Management, 8(12), 143. https://doi.org/10.5539/ijbm.v8n12p143

AL-Abdulrazag, B. (2009). The Impact of Public Investment on Private Investment in Jordan. Dirasat, Administrative Sciences, 36(2)

Al-Badarneh, K. M. (2016). The Role of Macro-Marketing Environmental Factors in Attracting Foreign Direct Investment: "Empirical Study at Qualified Industrial Zones (QIZ) in Jordan".

Al-Dmour, H., \& Alawi, B. (2008). Factors Affecting Investment Climate in Jordanian Free Zones: An Empirical Study. DIRASAT Journal of Administrative Sciences, 35(2).

Al-Nsour, M. (2008). The investment environment in Jordan between reality and ambition. Policy Forum, Al-Quds enter for Studies. Retrieved from http://chrome-extension://oemmndcbldboiebfnladdacbdfmadadm/http://cms.alqudscenter.org/fileman/Uploa $\mathrm{ds} / \mathrm{pdfs} / \mathrm{SY} .01 .03 .08 . \mathrm{pdf}$

Al-Shoura, M., \& Al Bakri, A. (2013). The evaluation of the investment environment in the industrial activity in Jordan. Journal of Accounting and Taxation, 5(1), 15-26. https://doi.org/10.5897/JAT2013.0101

Anadu, K., Kruttli, M., McCabe, P. E., Osambela, E., \& Shin, C. (2018). The Shift from Active to Passive Investing: Potential Risks to Financial Stability? https://doi.org/10.17016/FEDS.2018.060

Bakir, A., \& Alfawwaz, T. (2009).Determinants of foreign direct investment in Jordan. International Management Review, 5(2), 66-73.

Bandura, R. (2008). A survey of composite indices measuring country performance: 2008 update. New York: United Nations Development Programme, Office of Development Studies (UNDP/ODS Working Paper).

Beverly, S. (2009). Investment in human development as a social development strategy.

Biau, C., \& Pfister, M. (2014).Creating an environment for investment and sustainable development. 
Co-operation Report, 145. https://doi.org/10.1787/dcr-2014-16-en

Borgers, A., Derwall, J., Koedijk, K., \& Ter Horst, J. (2015). Do social factors influence investment behavior and performance? Evidence from mutual fund holdings. Journal of Banking \& Finance, 60, 112-126. https://doi.org/10.1016/j.jbankfin.2015.07.001

Büthe, T., \& Milner, H. V. (2008). The politics of foreign direct investment into developing countries: increasing FDI through international trade agreements?. American journal of political science, 52(4), 741-762. https://doi.org/10.1111/j.1540-5907.2008.00340.x

Cantwell, J. A., Dunning, J. H., \&Janne, O. E. (2004). Towards a technology-seeking explanation of US direct investment in the United Kingdom. Journal of International Management, 10(1), 5-20. https://doi.org/10.1016/j.intman.2003.12.002

Charron, N. (2016). Do corruption measures have a perception problem? Assessing the relationship between experiences and perceptions of corruption among citizens and experts. European Political Science Review, 8(1), 147-171. https://doi.org/10.1017/S1755773914000447

Cheng, S., Lin, K., \& Simmons, R. (2017). A city-level analysis of the distribution of FDI within China. Journal of Chinese Economic and Foreign Trade Studies, 10(1), 2-18. https://doi.org/10.1108/JCEFTS-01-2016-0002

Chung, W., \& Alcácer, J. (2002). Knowledge seeking and location choice of foreign direct investment in the United States. Management Science, 48(12), 1534-1554. https://doi.org/10.1287/mnsc.48.12.1534.440

Dauderstädt, P. (2013). Success factors in strategic corporate venturing.

Duce, M., \&Espana, D. B. (2003). Definitions of foreign direct investment (FDI): A methodological note. Banco de Espana.

Feldman, M., Hadjimichael, T., Lanahan, L., \&Kemeny, T. (2016). The logic of economic development: a definition and model for investment. Environment and Planning C: Government and Policy, 34(1), 5-21. https://doi.org/10.1177/0263774X15614653

Ferreira Neto, J. V., da Silva Gomes, S. M., Bruni, A. L., \& Dias Filho, J. M. (2017). Do Environmental Disasters Impact on the Volume of Socio-Environmental Investment and Disclosure of Brazilian Companies? In Advances in Environmental Accounting \& Management: Social and Environmental Accounting in Brazil (pp. 159-187). Emerald Publishing Limited. https://doi.org/10.1108/S1479-359820160000006006

Geltner, D., \& Ling, D. C. (2007).Indices for investment benchmarking and return performance analysis in private real estate. International Real Estate Review, 10(1), 93-118.

Goryunov, D. (2004). The Effectiveness Of Fdi Promotion In Transition Economies (Doctoral dissertation, National University).

Hanisch, A. T. (2019). Factors influencing the propensity of real estate investors in the UK to employ property derivatives. Journal of Property Investment \& Finance, 37(2), 194-214. https://doi.org/10.1108/JPIF-01-2018-0005

Hanisch, D. I. A. T. (2018). Factors Influencing the Propensity of Real Estate Investors in the UK to Employ Property Derivatives: A Survey (No. eres2018_73). European Real Estate Society (ERES). https://doi.org/10.15396/eres2018_73

Hussein, K. (2004). Ethical investment: empirical evidence from FTSE Islamic index. Islamic Economic Studies, $12(1)$.

Johnson, K., \& Lee, H. (2013). Impact investing: A framework for decision making. Boston: Cambridge Associates LLC.

Kengatharan, L., \&Kengatharan, N. (2014). The influence of behavioral factors in making investment decisions and performance: Study on investors of Colombo Stock Exchange, Sri Lanka. Asian Journal of Finance \& Accounting, 6(1), 1. https://doi.org/10.5296/ajfa.v6i1.4893

Kolodkin, B., Moreva, O., \& Sullivan, S. N. (2006).Best-Practice Guide for a Positive Business and Investment Climate. The Organization for Security and Co-operation in Europe (OSCE), Vienne.

Kusek, P., \& Silva, A. (2017). What Matters to Investors in Developing Countries: Findings from the Global Investment Competitiveness Survey. Global Investment Competitiveness Report, 19. https://doi.org/10.1596/978-1-4648-1175-3_ch1 
Liu, P., Koroma, S., Arias, P., \&Hallam, D. (2013). Trends and impacts of foreign investment in developing country agriculture: evidence from case studies. Food and Agriculture Organization of the United Nations (FAO).

Loewe, M., Blume, J., \&Speer, J. (2008). How favoritism affects the business climate: Empirical evidence from Jordan. The Middle East Journal, 62(2), 259-276. https://doi.org/10.2139/ssrn.2217964

Loewe, M., Blume, J., Schönleber, V., Seibert, S., Speer, J., \& Voss, C. (2007). The impact of favouritism on the business climate: A study on wasta in Jordan. https://doi.org/10.2139/ssrn.2218821

Loewendahl, H. (2018). Innovations in Foreign Direct Investment Attraction (No.IDB-TN-01572). Inter-American Development Bank. https://doi.org/10.18235/0001442

Louzi, B. M., \&Abadi, A. (2011).The impact of foreign direct investment on economic growth in Jordan. IJRRAS, $8(2), 253-258$.

Mainelli, M. (2007). The London Accord: from Copenhagen conundrum to climate-change investment. The Journal of Risk Finance, 8(2). https://doi.org/10.1108/jrf.2007.29408baf.002

Managi, S., Okimoto, T., \& Matsuda, A. (2012). Do socially responsible investment indexes outperform conventional indexes?. Applied Financial Economics, 22(18), 1511-1527. https://doi.org/10.1080/09603107.2012.665593

Mas' ud, A., Manaf, N. A. A., \&Saad, N. (2017).Validating a second-order model for oil and gas projects' investment climate scale. International Journal of Energy Sector Management, 11(1), 65-79. https://doi.org/10.1108/IJESM-08-2015-0003

Mollaesmaeili Dehshiri, H., Sameti, M., \& Sameti, M. (2012). Impact of Human Development Index and Rule of Law to Attract Foreign Direct Investment in Selected Developing Countries. University Library of Munich, Germany.

Moore, M., \& Schmitz, H. (2008). Idealism, realism and the investment climate in developing countries.

Moosa, I. (2002). Foreign direct investment: theory, evidence and practice. Springer. https://doi.org/10.1057/9781403907493

Mytelka, L. K., \& Barclay, L. A. (2004).Using foreign investment strategically for innovation. The European Journal of Development Research, 16(3), 531-560. https://doi.org/10.1080/0957881042000266615

Niu, D., Song, Z., Wang, M., \& Xiao, X. (2017). Improved TOPSIS method for power distribution network investment decision-making based on benefit evaluation indicator system. International Journal of Energy Sector Management, 11(4), 595-608. https://doi.org/10.1108/IJESM-05-2017-0005

Novikova, G., Chub, A., \&Gushina, J. (2016).Globalization and its socio-economic consequences. In 16 th International Scientific Conference (Vol. 1, pp. 1547-1555).

Panizza, U. (2017). The use of corruption indicators in sovereign ratings. Inter-American Development Bank. https://doi.org/10.18235/0000849

Park, C. H., \& Chu, H. (2018). Exploration on factors influencing Korean diaspora entrepreneurs' investment in the homeland: Evaluation of the WKBC and the WKBN. Asia Pacific Journal of Innovation and Entrepreneurship, 12(3), 338-362. https://doi.org/10.1108/APJIE-09-2018-0051

Potter, J. (2002). Embedding foreign direct investment. París: OCDE. Retrieved from http://www1.oecd. org/gov/regional-policy/2489910. pdf

Ramasamy, B., Yeung, M., \&Laforet, S. (2012). China's outward foreign direct investment: Location choice and firm ownership. Journal of world business, 47(1), 17-25. https://doi.org/10.1016/j.jwb.2010.10.016

Reilly, F. K., \& Brown, K. C. (2002). Investment analysis and portfolio management. Vytautas Magnus University Kaunas, Lithuania

Reiter, S. L., \& Steensma, H. K. (2010). Human development and foreign direct investment in developing countries: the influence of FDI policy and corruption. World Development, 38(12), 1678-1691. https://doi.org/10.1016/j.worlddev.2010.04.005

Salahuddin, M., \& Islam, M. R. (2008). Factors affecting investment in developing countries: A panel data study. The Journal of Developing Areas, 42(1), 21-37. https://doi.org/10.1353/jda.0.0011

Sherif, M. (2016). Ethical Dow Jones indexes and investment performance: international evidence. Investment 
Management and Financial Innovations, 13(2), 88-106. https://doi.org/10.21511/imfi.13(2-1).2016.08

Shotar, M. M., \&Abdulrazag, B. A. (2003).THe impact of foreign direct investment on economic growth in Jordan. Journal for International Business and Entrepreneurship Development, 1(1), 14-21. https://doi.org/10.1504/JIBED.2003.007803

Siegel, J. I., Licht, A. N., \& Schwartz, S. H. (2011).Egalitarianism and international investment. Journal of Financial Economics, 102(3), 621-642. https://doi.org/10.1016/j.jfineco.2011.05.010

Snieska, V., \&Zykiene, I. (2015). City attractiveness for investment: characteristics and underlying factors. Procedia-Social and Behavioral Sciences, 213, 48-54. https://doi.org/10.1016/j.sbspro.2015.11.402

Tang, K., \&Xiong, W. (2012). Index investment and the financialization of commodities. Financial Analysts Journal, 68(6), 54-74. https://doi.org/10.2469/faj.v68.n6.5

Tuman, J. P., \& Emmert, C. F. (2004). The political economy of US foreign direct investment in Latin America: a reappraisal. Latin American Research Review, 9-28. https://doi.org/10.1353/lar.2004.0060

Waluyo, D. B. (2018). Globalisation and deglobalisation: The Indonesian perspective. BIS Paper, (100k).

Watson, M., \& Hay, C. (2003). The discourse of globalisation and the logic of no alternative: rendering the contingent necessary in the political economy of New Labour. Policy \& Politics, 31(3), 289-305. https://doi.org/10.1332/030557303322034956

Yıldırım, M. O., \& Yıldırım, A. E. (2017). The influence of consumption and investment on unemployment in Turkey: A SVAR approach. Ekonomika (Economics), 96(1), 74-92. https://doi.org/10.15388/Ekon.2017.1.10665

Zeibote, Z., Volkova, T., \& Todorov, K. (2019). The impact of globalization on regional development and competitiveness: cases of selected regions. https://doi.org/10.9770/ird.2019.1.1(3)

Zuraiqat, Z., \& Gharaibeh, M. (2011). Financial Liberalization and Investment Sensitivity to the Cash Flow. European Journal of Economics, Finance and Administrative Sciences, 4(2)

\section{Copyrights}

Copyright for this article is retained by the author(s), with first publication rights granted to the journal.

This is an open-access article distributed under the terms and conditions of the Creative Commons Attribution license (http://creativecommons.org/licenses/by/4.0/). 